\title{
Costing Dental Restorations in Public Sector Dental Clinics
}

Type: Article

Abstract:

The objective of this study is to share cost analysis methodology and to obtain cost estimates for posterior restorations in public sector dental clinics. Two urban and 2 rural dental clinics in Selangor state were selected. Only cases of 1 posterior restoration per visit by dental officers were included over 6 months. One capsulated amalgam type, 1 capsulated tooth-colored, and 1 non-capsulated tooth-colored material were selected. A clinical pathway form was formulated to collect data per patient. Annual capital and recurrent expenditures were collected per clinic. The mean cost of an amalgam restoration was RM 30.96 (sdRM 7.86); and tooth-colored restorations ranged from RM 33.00 (sdRM 8.43) to RM 41.10 (sdRM 10.61). Wherein 1 USD = RM 2.8. Restoration costs were $35 \%$ to $55 \%$ higher in clinics in rural areas than in urban areas. The findings demonstrate economy of scale for clinic operation and restoration costs with higher patient load. Costs per restoration were higher in rural than in urban dental clinics. More studies are recommended to address the dearth of dental costs data in Malaysia.

\begin{tabular}{|c|l|}
\hline Author & $:$ Khairiyah, A. M. \\
& $:$ Razak, I. A. \\
& $:$ Raja-Latifah, R. J. \\
& $:$ Tan, B. S. \\
& $:$ Norain, A. T. \\
& $:$ Noor-Aliyah, I. \\
& $\quad$ Natifah, C. S. \\
& Rauzi, I. \\
\hline Source & Asia-Pacific Journal of Public Health \\
\hline ISSN & $1010-5395$ \\
\hline DOI & $10.1177 / 1010539509331788$ \\
\hline Volume (Issue) & $21(2)$ \\
\hline Page & $184-195$ \\
\hline Year & 2009 \\
\hline
\end{tabular}

Keyword:

Costs, dental restorations, public sector, Malaysia

Please Cite As:

KHAIRIYAH, A. M., RAZAK, I. A., RAJA-LATIFAH, R. J., TAN, B. S., NORAIN, A. T., NOOR-ALIYAH, I., NATIFAH, C. S. \& RAUZI, I. 2009. Costing Dental 
Restorations in Public Sector Dental Clinics. Asia-Pacific Journal of Public Health, 21, 184-195.

URL:

- http://apps.webofknowledge.com search via Accession No >> 000266062100009

- http://www.scopus.com/inward/record.url?eid=2-s2.062849114765\&partnerID=40\&md5=530542e8c177c938c38ba717b7096619

- http://aph.sagepub.com/content/21/2/184

- $\quad$ http://www.ncbi.nlm.nih.gov/pubmed/19190002

- http://www.myjurnal.my/public/article-view.php?id=16871 